information of import to catalysis. Gorokhovatskii et al. have found that the yield in the propylene-to-acrolein reaction is virtually independent of the phase relations in a $\mathrm{CuO} / \mathrm{Cu}_{2} \mathrm{O} / \mathrm{Cu}^{0}$ catalyst system (16). The data we have reported indicate that crystal structure alone cannot be used as a criterion for the reactivity of the surface with propylene. For example, we find that of the six species investigated which react readily with propylene at $\leq 500^{\circ} \mathrm{C}$, four contain a new phase and two do not. Even within a binary family, variation occurs. All three $\mathrm{V} / \mathrm{Mo}$ samples react readily with propylenc although one exhibits a new phase and two do not. These factors, plus others demonstrated in this work-the dependence of crystal structure on method of preparation and the complicated nature of the reacted mixed oxidemake any effort to relate crystal structure and catalytic properties extremely tenuous.

\section{REFERENCES}

1. Rashrin, J. A., and Pierron, E. D., J. Catalysis 6, 332 (1966).

2. Pierron, E. D., Rashrin, J. A., and Roth, J. F., J. Catalysis 9, 38 (1967).

3. LevY, R. M., to be published.

4. Adams, C. R., Voge, H. H., Morgan, C. Z., and Armstrona, W. E., J. Catalysis 3, 379 (1964).

5. Batist, Рh. A., Lippens, B. C., and Schuit, G. C. A., J. Catalysis 5, 55 (1966)
6. For example see the following U. S. Patents for the specific binary oxides: $\mathrm{Sb} / \mathrm{W}$, $\mathrm{Bi} / \mathrm{Mo}$, and $\mathrm{Sb} / \mathrm{Mo}, 2,904,580 ; \mathrm{Bi} / \mathrm{W}$, $3,232,977$; W/Mo, 2,439,880; V/Mo, 3,277,$017 ; \mathrm{Bi} / \mathrm{V}, 3,232,978$.

7. Andersson, G., and Magnéli, A., Acta Chem. Scandinavica 4, 793 (1950).

8. Bleijenbera, A. C. A. M., Lippens, B. C., ANd Schuit, G. C. A., J. Catalysis 4, 581 (1965).

9. Gal'perin, E. L., Erman, L. Ya., Kolchin, I. K., Belova, M. A., ANd Bhernyshev, K. S., Zh. Neorgan. Khim. 11, 2125 (1966).

10. Roth, R. S., AND Waring, J. L., Am. Mineralogist 48, 1348 (1963).

11. Munch, R. H., and Pierron, E. D., J. Catalysis 3, 406 (1964).

12. Kolchin, I. K., Bolkov, S. S., ANd Margolts, L. YA., Neftelihimiya 4, 301 (1964).

13. Kolchin, I. K., GaL'PeriN, BolKov, S. S., aND Margolis, L. YA., Neftekhimiya 5, 111 (1965)

14. Batist, Рh. A., Kapteijns, C. J., Lippens, B. C., ANd Schuit, G. C. A., J. Catalysis 7, 33 (1967).

15. Magnéli, A., Acta Cryst. 6, 495 (1958).

16. Goroknovatskit, Ya. B., Vovyanko, I. I., and Rubanik, M. YA., Kinetika $i$ Kataliz 7, 76 (1966)

RiChaRd M. LeVY

Central Research Department

Monsanto Company

St. Louis, Missouri 63166

Received March 5, 1968;

revised May 18, 1968

\title{
Catalytic Hydrogen Transfer between Cyclohexane and Benzene
}

In an effort to establish conditions for the study of hydrogen transfer at catalytic surfaces under conditions of thermodynamic equilibrium, we have found that the reaction

$$
{ }^{*} \mathrm{C}_{6} \mathrm{H}_{6}(\mathrm{~g})+\mathrm{C}_{6} \mathrm{H}_{12}(\mathrm{~g}) \rightarrow \mathrm{C}_{6} \mathrm{H}_{6}(\mathrm{~g})+{ }^{*} \mathrm{C}_{6} \mathrm{H}_{12}(\mathrm{~g})
$$

where ${ }^{*} \mathrm{C}$ is an isotopically tagged carbon atom, occurs readily on a variety of cata- lysts, including transition and nontransition metals, supported and nonsupported.

The experiments were conducted by flowing a mixture of benzene and cyclohexane, containing radioactive benzene, in a stream of purified $\mathrm{He}$ over a fixed catalytic bed. The reactor outlet was fractionated by gas chromatography, the fractions collected by freezing at liquid $\mathrm{N}_{2}$ temperature, and 
analyzed by liquid scintillation counting techniques. The variables investigated were catalyst, temperature, $\left[\mathrm{C}_{6} \mathrm{H}_{12}\right] /\left[\mathrm{C}_{6} \mathrm{H}_{6}\right]$ ratio, and contact time.

Typical results on Au-MgO (2 wt \% Au) are presented in Fig. 1, where the conversion $\alpha=\left[{ }^{*} \mathrm{C}_{6} \mathrm{H}_{12}\right] /\left[{ }^{*} \mathrm{C}_{6} \mathrm{H}_{6}\right]_{0}$ is plotted against the contact time, $\tau=F / v$ at $205^{\circ} \mathrm{C}$ and $\left[\mathrm{C}_{6} \mathrm{H}_{12}\right] /\left[\mathrm{C}_{6} \mathrm{H}_{6}\right] \cong 2.0$. The suffix 0 in the expression of $\alpha$ refers to the initial conditions; in the expression of $\tau, F$ is the catalyst fraction void $(\sim 0.3)$ and the space velocity $v=f T / 273 V P(f$, flow rate; $T$, temperature; $V$, apparent catalyst volume; $P$, total pressure). In Table 1 values of the conversion $\alpha$ at various temperatures for supported Pt and Au are reported.
TABLE 1

Conversion $\alpha$ for Reaction (1) over Different Catalysts

\begin{tabular}{ccccc}
\hline Catalyst & $\begin{array}{c}\text { Temp. } \\
\left({ }^{\circ} \mathrm{C}\right)\end{array}$ & $\frac{\left[\mathrm{C}_{6} \mathrm{H}_{\mathrm{I} 2}\right]}{\left[\mathrm{C}_{6} \mathrm{H}_{6}\right]}$ & $\begin{array}{c}\tau \\
(\mathrm{sec})\end{array}$ & $\alpha$ \\
\hline $\begin{array}{c}\mathrm{Pt}-\mathrm{Al}_{2} \mathrm{O}_{3} \\
(0.6 \%)\end{array}$ & $157^{\circ}$ & 3.5 & 3.5 & $1 \times 10^{-2}$ \\
$\begin{array}{c}\mathrm{Pt}-\mathrm{Al}_{2} \mathrm{O}_{3} \\
(0.6 \%)\end{array}$ & $182^{\circ}$ & 3.5 & 3.3 & $1 \times 10^{-1}$ \\
$\begin{array}{c}\mathrm{Au}-\mathrm{Al}_{2} \mathrm{O}_{2} \\
(10 \%)\end{array}$ & $233^{\circ}$ & 4.5 & 0.1 & $7.7 \times 10^{-3}$ \\
$\begin{array}{c}\mathrm{Au}-\mathrm{MgO}^{a} \\
(2 \%)\end{array}$ & $235^{\circ}$ & 6.2 & 2.8 & $2.1 \times 10^{-2}$ \\
$\begin{array}{c}\left(2 \mathrm{Au}^{\circ}-\mathrm{MgO}^{b}\right. \\
(2 \%)\end{array}$ & $205^{\circ}$ & 59 & 0.7 & $1.8 \times 10^{-2}$ \\
\hline
\end{tabular}

a By precipitation.

${ }^{b}$ By impregnation.

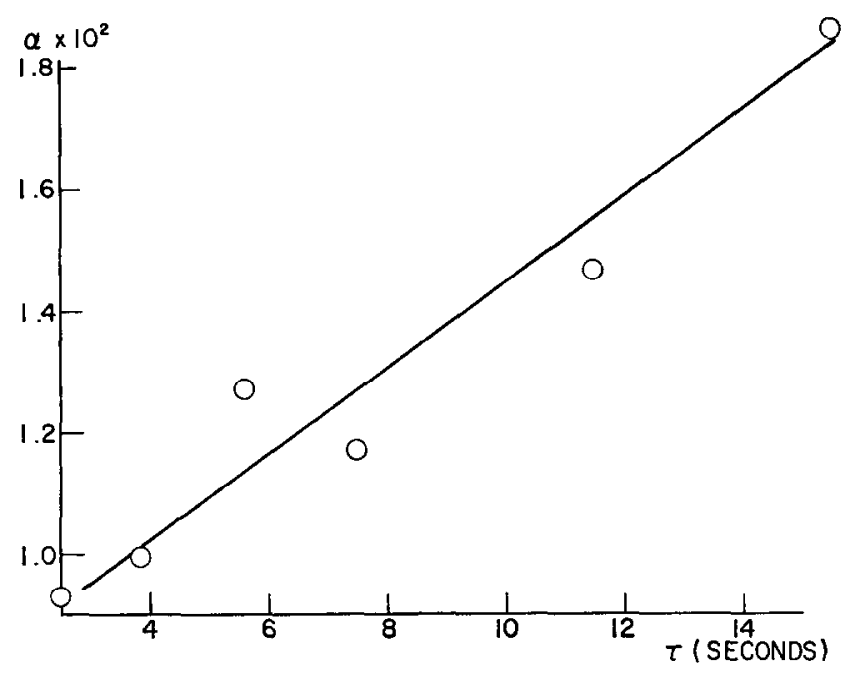

FIG. 1. Conversion of reaction (1) $\alpha=\left[{ }^{*} \mathrm{C}_{6} \mathrm{H}_{12}\right] /\left[{ }^{*} \mathrm{C}_{6} \mathrm{H}_{6}\right]_{0}$, as a function of contact time, $\tau$, for Au-MgO $\left(2\right.$ wt \%), $203^{\circ} \mathrm{C},\left[\mathrm{C}_{8} \mathrm{H}_{12}\right] /\left[\mathrm{C}_{6} \mathrm{H}_{8}\right]=2.0$.

No appreciable reaction was detected on $\mathrm{CoFe}_{2} \mathrm{O}_{4}$ at temperatures up to $235^{\circ} \mathrm{C}$ and contact times up to 2 sec.

The results provide experimental evidence that the transfer of $\mathrm{H}_{2}$ between $\mathrm{C}_{6} \mathrm{H}_{12}$ and $\mathrm{C}_{0} \mathrm{H}_{6}$ occurred in a readily measurable fashion on $\mathrm{Pt}$ and $\mathrm{Au}$ in the temperature range $150^{\circ}$ to $235^{\circ} \mathrm{C}$. These results are consistent with and related to earlier investigations (1) on the exchange reaction

$$
{ }^{*} \mathrm{C}_{6} \mathrm{II}_{6}(\mathrm{~s})+\mathrm{C}_{6} \mathrm{H}_{6}(\mathrm{~g}) \rightarrow{ }^{*} \mathrm{C}_{6} \mathrm{H}_{6}(\mathrm{~g})+\mathrm{C}_{6} \mathrm{H}_{6}(\mathrm{~s})
$$

where $s$ refers to adsorbed phase. In this instance, it was found that reaction (2) look place readily on $\mathrm{Pt}$ at temperatures as low as $80^{\circ} \mathrm{C}$. Although the detailed mechanism of reaction (2) was not uncovered at that time, adsorbed hydrogen was a likely intermediate present at the surface during the occurrence of reaction (2). Similarly, during these earlier studies, it was found that by flowing a stream of $\mathrm{C}_{6} \mathrm{H}_{12}$ on a $\mathrm{Pt}$ catalyst, onto which ${ }^{*} \mathrm{C}_{6} \mathrm{H}_{6}$ was chemisorbed, radioactivity could be easily detected in the effluent stream. It was not ascertained whether the radioactive compound was $\mathrm{C}_{6} \mathrm{H}_{6}$ and/or $\mathrm{C}_{6} \mathrm{H}_{12}$.

The present results indicate that the 
interaction of $\mathrm{C}_{6} \mathrm{H}_{12}$ with the catalytic surface was a dehydrogenative chemisorption producing adsorbed $\mathrm{H}_{2}$, which, in the presence of $\mathrm{C}_{6} \mathrm{H}_{6}$, induced the hydrogenative desorption of the latter in the form of $\mathrm{C}_{6} \mathrm{H}_{12}$. Thus, reaction (1) may be visualized to occur as a sequence of two steps, namely,

$$
\begin{aligned}
& \mathrm{C}_{6} \mathrm{H}_{12}(\mathrm{~g}) \rightarrow \mathrm{C}_{6} \mathrm{H}_{6}(\mathrm{~g})+6 \mathrm{H}(\mathrm{s}) \\
& { }^{*} \mathrm{C}_{6} \mathrm{H}_{5}(\mathrm{~g})+6 \mathrm{H}(\mathrm{s}) \rightarrow{ }^{*} \mathrm{C}_{66} \mathrm{H}_{12}(\mathrm{~g})
\end{aligned}
$$

Support for this view was obtained by initially feeding to the reactor $\mathrm{C}_{6} \mathrm{H}_{12}$ only. Under these conditions $\left(200^{\circ} \mathrm{C}\right)$ the formation of $\mathrm{H}_{2}$ was detected. Introduction of $\mathrm{C}_{6} \mathrm{H}_{6}$ in the inlet stream totally suppressed the appearance of gas-phase $\mathrm{H}_{2}$. The results of Table 1 indicate that $\mathrm{Pt}$ is the most active of the catalysts reported. This conclusion is in agreement with the large body of experimental results on the catalytic hydrogenation of benzene. This is not unexpected since kinetically reaction step (1b) [or the reverse of reaction step (1a) ] represents one stage of the overall hydrogenation reaction of benzene.

During the occurrence of reaction (1) a chemical equilibrium between gas and surface phases is established. The establishment of this equilibrium is supported by the experimental observations of constant reaction conversion for periods of several days of operation. Similarly the ratio of benzene to cyclohexane was found invariant in the reactor space and in time. Thus reaction (1) may be used as a kinetic tool for the study of the rate of hydrogen transfer at catalytic surfaces under conditions of chemical equilibrium. The chemical potential of the reaction intermediate, adsorbed $\mathrm{H}_{2}$, is a function of the ratio of benzene to cyclohexane at equilibrium. This ratio is constant and known during the occurrence of reaction (1). Thus, by obtaining experimental rate results at various ratios of benzene to cyclohexane, the influence of the chemical potential of adsorbed $\mathrm{H}_{2}$ upon the rate of reaction (1) may be brought to light. Since adsorbed $\mathrm{H}_{2}$ is the common intermediate of the catalytic hydrogenation of aromatics, we conclude that reaction (1) represents a useful and interesting kinetic tool for the study and classification of catalytic behavior in the hydrogenation of aromatic hydrocarbons.

\section{ACKNOWLEDGMENT}

Acknowledgement is made to the donors of The Petroleum Research Fund, administered by the American Chemical Society, for support of this research.

\section{REFERENCE}

1. Brundege, J. A., and Parravano, G., J. Catalysis 2, 380 (1963).

\section{G. Parravano}

Department of Chemical and Metallurgical Engineering

University of Michigan

Ann Arbor, Michigan

Received March 5, 1968

\section{The Ratio of Absorption Coefficients of Pyridine Adsorbed on Lewis and Brönsted Acid Sites}

Spectroscopic studies of adsorbed bases, in particular pyridine, have become well established techniques for investigating the surface acidity of catalysts $(1-6)$. Brönsted and Lewis acidity can readily be detected and distinguished. In many cases, it is of in- terest not only to determine the type of acid sites but also their relative numbers. Specific absorption bands in the spectrum of chemisorbed pyridine near 1545 and 1450 $\mathrm{cm}^{-1}$ can be assigned to pyridine adsorbed on Brönsted and Lewis acid sites, respec- 